\title{
An epitaph for Professor Otmar Pachinger, MD
}

\section{Peter Probst}

(C) Springer-Verlag GmbH Austria, part of Springer Nature 2020

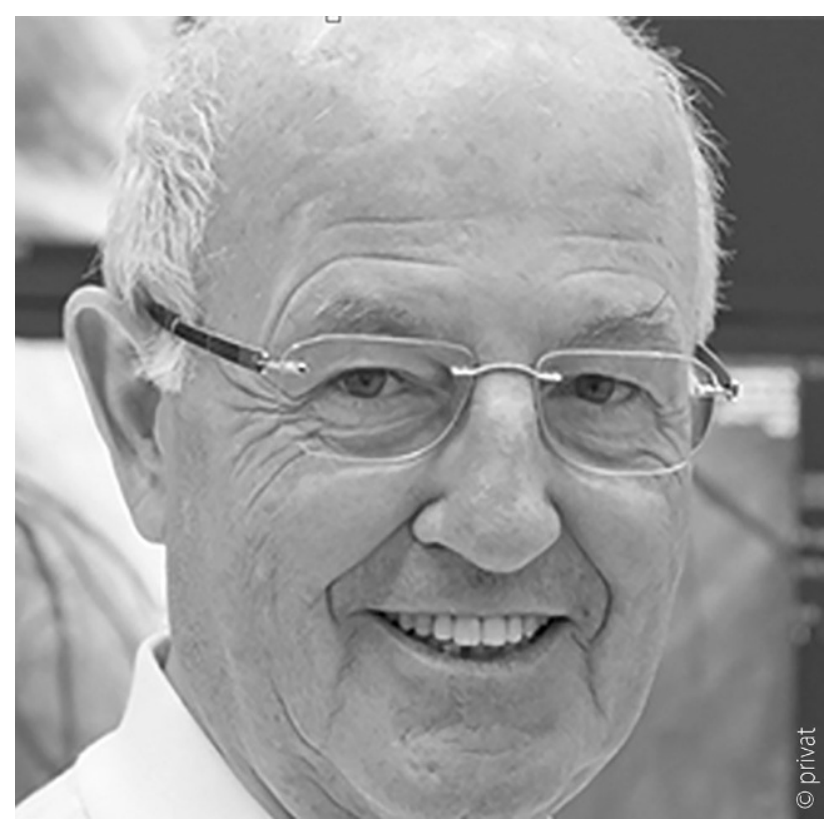

After a long year of illness, Professor Otmar Pachinger passed away on October 7th, 2019 and was privately laid to rest in the presence of his family in his hometown of Wels, Austria. His official memorial service took place with his relatives, friends, colleagues, dignitaries and many patients on October 29th, 2019 at Wilten Abbey in Innsbruck.

Professor Pachinger was born in Wels on March 29th, 1944 and graduated with highest honors from high school in 1962. He then studied medicine at the University of Vienna and graduated summa cum laude in 1968. After his first two years of internship

Professor P. Probst, MD ( $\varangle)$

Sieveringer Straße 54, 1190 Vienna, Austria

peter.probst@aon.at in Vienna, he spent more than one year with the renowned pharmacologist Professor Albrecht Fleckenstein in Freiburg, Germany, who was the discoverer of the calcium antagonists. In Freiburg, Pachinger also met Carolyn, an American foreign language teacher, who would later become his wife. After his stay in Freiburg, he decided to go to the United States, where he worked with the legendary basic researcher Professor Richard Bing in Pasadena, California.

Otmar Pachinger, however, never lost sight of his original calling, which was to take care of patients, and so he transferred to Professor Melvin, Judkins, one of the co-innovators of the cardiac catheters still in use today, at Loma Linda University in California. There, he laid the foundation for his later work as an interventional cardiologist.

In 1972, he married Carolyn in Wayland, Massachusetts. His wife stood by his side ever since.

Professor Pachinger returned to Vienna in 1974, where the two of us became the heads of the Cath Lab at the Department of Cardiology, Chief Prof. Fritz Kaindl. After some initial difficulties, mostly due to outdated equipment, our relocation to the new cardiac clinic in 1976 served to create a far better working environment. It was about this time that Prof. Andreas Grüntzig made his first attempts to dilate stenosed coronary arteries with balloon catheters. This revolutionary discovery was then presented to a group of selected cardiologists in Zurich and led to the first coronary artery dilation in Austria in 1979 at the Department of Cardiology, University of Vienna.

The following years were marked by hard pioneer work, during which the field of cardiology was transformed from a conservative discipline into a highly interventional specialty. Professor Pachinger stood out with commitment, irrespective of any regular working hours, which made him a pioneer of these newly developed interventional methods. It was also 
at this time that he became interested in novel diagnostic procedures, especially the up-and-coming isotope method. He thus had an isotope camera installed at the Department of Cardiology, a highly unusual initiative at that time.

In 1979, Professor Pachinger qualified as a lecturer with the results of his "Quantitative assessment of regional myocardial dysfunction in coronary artery disease-a comparison of radioisotope methods with hemodynamic and angiographic techniques".

Some time was reserved for sports, which was why his Wednesday evenings where exclusively devoted to soccer.

Between 1975 and 1981, he was also pleased to welcome his daughters Linda, Christine and Lisa into the world of medicine.

In 1986, Professor Pachinger took his next big step when he became Chief of Cardiology at a hospital in Wels, which was run by the Order of the Sisters of Mercy. There, he established a department of cardiology, which was to acquire an excellent reputation. With his outstanding way of working with his patients, many of them, including some from Vienna, came from far and near to visit him wherever he was.

The early 1990's were marked by upcoming new interventions such as the Rotablator and methods such as coronary stent implantation. These methods were also pushed forward by Otmar Pachinger.

After this successful period of time, Professor Pachinger became Chief of Internal Medicine at the University of Innsbruck in 1997. He again started to build up an institution which soon acquired international reputation. One of his great merits was to organize an "infarct network" to offer immediate care in acute situations. As head of the Innsbruck University Clinic, he still stood at the operating table on a daily basis and managed the most complicated interventional operations on his own. In addition, he also trained many young colleagues, some of whom were to become the heads of important cardiology departments at hospitals in Austria. Otmar Pachinger also established annual conventions, which again gained an excellent reputation and always enjoyed broad international attendance.

Professor Pachinger's scientific work is equally notable: 320 original publications, 38 reviews, 16 chapters in books and 16 editorials. Apart from that, he was an excellent and highly demanded speaker at meetings. Since 2010, he still found time to serve as Secretary and later as an Honorary President for the Austrian Heart Foundation Charity (which is located in Vienna!).

Professor Pachinger received multiple honors, including the ring of honor of the city of Wels, an honorary medal from the state of Tyrol in 2014, and honorary memberships of the Medical Society of Upper Austria, the Austrian Society of Surgery and the Austrian Society of Internal Medicine. He became President and Honorary President of the Austrian Society of Cardiology in 1988 and 2016, respectively, and was also an active member of the most important international societies of cardiology. Witnessing the establishment of the European Society of Cardiology, he became one of its first fellows.

Due to his interventional work, Professor Pachinger was exposed to X-ray irradiation for over forty years and thus possibly fell victim to his work for the sake of his patients. In his last week of life, he still gave three talks on cardiology and saw patients until his final day, despite his reduced physical condition.

All of us, his friends and patients, together with the cardiologists of Austria, have lost a friend, an outstanding physician and a truly irreplaceable personality.

Conflict of interest P. Probst declares that he has no competing interests.

Publisher's Note Springer Nature remains neutral with regard to jurisdictional claims in published maps and institutional affiliations. 